\title{
Hawaii Pineapple: The Rise and Fall of an Industry
}

\author{
Duane P. Bartholomew ${ }^{1}$ \\ Department of Tropical Plant and Soil Sciences, University of Hawaii at Manoa, 3190 Maile Way, \\ Honolulu, HI 96822
}

\author{
Richard A. Hawkins \\ Department of History, University of Wolverhampton, Wulfruna Street, Wolverhampton WV1 1LY, U.K. \\ Johnny A. Lopez \\ Valent BioSciences Corp., 870 Technology Way, Libertyville, IL 60048
}

Additional index words. Ananas comosus var. comosus, economic history, canning, fresh fruit, global pineapple industry, 'Smooth Cayenne', 'MD-2', 'CO-2'

\begin{abstract}
The date pineapple (Ananas comosus var. comosus) was introduced to Hawaii is not known, but its presence was first recorded in 1813. When American missionaries first arrived in Hawaii in 1820, pineapple was found growing wild and in gardens and small plots. The pineapple canning industry began in Baltimore in the mid-1860s and used fruit imported from the Caribbean. The export-based Hawaii pineapple industry was developed by an entrepreneurial group of California migrants who arrived in Hawaii in 1898 and the well-connected James D. Dole who arrived in 1899. The first profitable lot of canned pineapples was produced by Dole's Hawaiian Pineapple Company in 1903 and the industry grew rapidly from there. Difficulties encountered in production and processing as the industry grew included low yields resulting from severe iron chlorosis and the use of low plant populations, mealybug wilt that devastated whole fields, inadequate machinery that limited cannery capacity, and lack of or poorly developed markets for the industry's canned fruit. The major production problems were solved by public- and industry-funded research and innovation in the field and in the cannery. An industry association and industry-funded cooperative marketing efforts, initially led by James Dole, helped to expand the market for canned pineapple. Industry innovations were many and included: selection of 'Smooth Cayenne' pineapple as the most productive cultivar with the best quality fruit for canning; identification of the cause of manganese-induced iron chlorosis and its control with biweekly iron sulphate sprays; the use of mulch paper and the mechanization of its application, which increased yields by more than $20 \mathrm{t} \cdot \mathrm{ha}^{-1}$; and the invention of the Ginaca peeler-corer machine, which greatly sped cannery throughput. Nematodes were also a serious problem for the industry, which resulted in the discovery and development of nematicides in the 1930s. As a result, by 1930 Hawaii led the world in the production of canned pineapple and had the world's largest canneries. Production and sale of canned pineapple fell sharply during the world depression that began in 1929. However, the formation of an industry cartel to control output and marketing of canned pineapple, aggressive industry-funded marketing programs, and rapid growth in the volume of canned juice after 1933 restored industry profitability. Although the industry supported the world's largest pineapple breeding program from 1914 until 1986 , no cultivars emerged that replaced 'Smooth Cayenne' for canning. The lack of success was attributed in part to the superiority of 'Smooth Cayenne' in the field and the cannery, but also to the difficulty in producing defect-free progeny from crosses between highly heterozygous parents that were self-incompatible. Production of canned pineapple peaked in 1957, but the stage was set for the decline of the Hawaii industry when Del Monte, one of Hawaii's largest canners, established the Philippine Packing Corporation (PPC) in the Philippines in the 1930s. The expansion of the PPC after World War II, followed by the establishment of plantations and canneries by Castle and Cooke's Dole division in the Philippines in 1964 and in Thailand in 1972, sped the decline. The decline occurred mainly because foreign-based canneries had labor costs approximately one-tenth those in Hawaii. As the Hawaii canneries closed, the industry gradually shifted to the production of fresh pineapples. During that transition, the pineapple breeding program of the Pineapple Research Institute of Hawaii produced the MD-2 pineapple cultivar, now the world's pre-eminent fresh fruit cultivar. However, the first and major beneficiary of that cultivar was Costa Rica where Del Monte had established a fresh fruit plantation in the late 1970s. Dole Food Co. and Maui Gold Pineapple Co. continue to produce fresh pineapples in Hawaii, mostly for the local market. All of the canneries eventually closed, the last one on Maui in 2007.
\end{abstract}

The history of the Hawaiian pineapple (Ananas comosus var. comosus) industry is richly documented, but until the recent books of Hawkins (2011) and Larsen and Marks (2010), much of the information was in documents and publications of more limited

Received for publication 13 June 2012. Accepted for publication 23 July 2012 .

This paper was part of the workshop "History of Hawaiian Pomology" held 25 Sept. 2011 at the ASHS Conference, Waikoloa, HI, and sponsored by the History of Horticultural Science (HIST) and Pomology (POM) Working Groups.

We thank Richard Manshardt, Donald P. Gowing, and Myrtle Dillon for their helpful comments and editorial advice.

${ }^{1}$ To whom reprint requests should be addressed; e-mail duaneb@hawaii.edu. scope or having limited availability (Auchter, 1946, 1951; Dole, 1929; Dole and Porteus, 1990; Kehlor, 1992; Ten Bruggencate, 2004; Oehm, University of Hawai'i at Mānoa Library, Hawaiian Collection, 1953). The profusely illustrated book by Larsen and Marks (2010) provides comprehensive coverage of the canning industry and includes considerable oral history of that industry. Larsen spent more than 20 years at Dole and the book contains extensive interviews with industry workers and leaders. The book lacks an index, a limitation given the wealth of information it contains.

In this article, we provide an overview of the rise and decline of the industry as a whole and highlight some of the events that promoted its development and were responsible for its decline. Although the focus of this article is on pineapple production and canned product, Larsen and Marks (2010) devote an entire chapter to pineapple juice, which became an important byproduct of the industry after 1933 and eventually exceeded 13 million cases in 1955. One thing made clear from the wealth of information included in these references is that we can only touch on the array of issues and events that resulted in the rise and fall of the Hawaiian pineapple industry in this article.

\section{PINEAPPLE IN THE UNITED STATES AND HAWAII-19TH CENTURY}

The date that pineapple was introduced into Hawaii is lost in history, but the first record of pineapple in Hawaii was a 21 Jan. 1813 note in Don Francisco de Paula Marín's diary stating "This day I planted pineapples and an orange tree" (Collins, 1960). Collins (1960) asserts that the note indicated an ordinary 
event and so likely was not the date of first introduction. Larsen and Marks (2010) conclude that pineapple was well established in Hawaii in both wild and cultivated states before missionaries arrived from New England in 1820 and suggest multiple possibilities by which pineapple could have arrived in the islands. However, Marin's note is the first verifiable record of its presence. Pineapple was not again noteworthy until 1849 to 1851 when some 21,000 fruits were transported from the Kona area of Hawaii to Honolulu and then to California after gold was discovered there (Gortner et al., 1963). Spoilage during shipment was a serious problem and losses were high because refrigerated shipping did not exist. As a result, there were infrequent small shipments of fresh pineapples from Hawaii to California between 1851 and 1903 (Gortner et al., 1963).

From $\approx 1815$ until 1900, when Hawaii was incorporated as a U.S. Territory, the principal agricultural commodity exported from Hawaii was sugar. The profitability of agriculture exports from Hawaii during this period was determined mainly by land availability and tenure, availability of labor, and U.S. tariff regulations. For sugar, the land tenure issue was solved by the Great Mahele, a land redistribution act proposed by King Kamehameha III in 1830 , enacted in 1848 , and amended in 1850 that allowed foreigners to buy and lease land. Tariffs and duties on exports to the United States were eliminated by the Reciprocity Treaty of 1875 . The factors impacting the profitability of fresh pineapple shipments were similar to those of sugar but included a lack of refrigerated transport, which did not exist until the early 1880 s. Its appearance about coincided with the development of improved methods of canning, in particular the invention of the double-seamed tinned steel can.

Nicholas Appert published the methods for preserving meats, vegetables, and fruits in glass jars in 1810. A British patent on the preservation of foods in tinplated cans and glass jars was issued to Peter Durand, a colleague of Appert, in 1810 and gave rise to the name "canning" (Larsen and Marks, 2010, p. 30). A canning industry was established in Baltimore in 1819 and by 1850 , five canning companies existed that mainly processed oysters (Hawkins, 1995). However, until relatively late in the 19th century, canned commodities remained beyond the reach of all but the wealthy and government troops on campaigns, e.g., the American Civil War.

Baltimore became the canning center of America. Pineapple, initially imported from the Bahamas and later also from Cuba, was first canned there in 1865 (Hawkins, 1995). The fruits were of poor quality because they were picked green to reduce rotting during the 25- to 30-d sailing trip from the Bahamas. However, green pineapples "degreen," but the quality and flavor only diminish with storage time. Initially, the Baltimore pineapple canning industry was small because all work was done by hand. Machinery developed between $\approx 1870$ and 1900 that could core, slice, and shred pineapples helped the industry to grow. The ring-shaped slices so characteristic of premium canned pineapple originated in the Baltimore canneries and mechanical slicers were particularly popular with canners. A contour peeler that could peel four pineapples per minute was developed and patented in 1893 (Hawkins, 1995), but it was not particularly successful so much of the peeling work continued to be done by hand. Some 70 years later the Dole division of Castle and Cooke developed and patented a contour pineapple peeler. It too was not successful, in part as a result of the difficulty in keeping the knives sharp (Larsen and Marks, 2010, p. 236).

Duties and tariffs imposed in 1894 and 1897 by the United States at the instigation of pineapple growers in Florida, and an additional tariff passed in 1909, were largely responsible for the decrease in shipments of pineapples from the Bahamas to Baltimore and thus for the demise of the Baltimore pineapple canning industry (Hawkins, 1995). Coincident with, but unrelated to, the demise of the Baltimore pineapple canning industry was the rise of the Hawaii industry after the annexation of the Republic of Hawaii by the United States in 1898.

The earliest record of pineapple being canned in Hawaii was when the Kona Fruit Preserving Co., founded in 1882 in North Kona by John Douglas Ackerman and Waldemar Muller, sent samples of canned pineapple to Honolulu. The fruit was reported to be of excellent flavor. However, the business apparently was unprofitable and only survived a few months (Hawkins, 2011; Larsen and Marks, 2010, p. 51).

The basis for the modern Hawaii industry was begun when John Kidwell, a trained horticulturist, arrived in Honolulu from San Francisco in 1882 and established a nursery in Manoa Valley. Kidwell was encouraged by Charles Henson, a local horticulturist and fruit broker, to grow pineapples because he liked to include a few fresh pineapples in his banana shipments to the U.S. mainland (Auchter, 1951). In 1885, Kidwell started a pineapple farm with locally available plants, but their fruit was of poor quality (Hawkins, 1997). That prompted him to search for better cultivars. A report in The Florida Agriculturist about 'Smooth Cayenne', a pre-Columbian cultivar first collected in French Guyana (Coppens d'Eeckenbrugge et al., 2011), prompted the importation of 12 plants. An additional 1000 plants were obtained from Jamaica in 1886, and an additional 31 cultivars, including 'Smooth Cayenne', were imported from various locations around the world. 'Smooth Cayenne' was reported to be the best of the introductions and, at the time of Henson's premature death from tuberculosis in 1886 (Anonymous, 1886), Kidwell had 4.05 ha (10 acres) of pineapple under cultivation. R.W. Jordan shipped an additional one million 'Smooth Cayenne' plants obtained in Australia to his brother's nursery in Honolulu in 1896 (Auchter, 1951). The pineapple cultivar that would form the foundation of the future Hawaii industry had become well established in the islands, presumably because it was vigorous, productive, tolerant of most pests and diseases, and had fruit of good quality that canned well.

\section{RISE OF THE COMMERCIAL HAWAIIAN PINEAPPLE INDUSTRY-20TH CENTURY}

The commercial Hawaiian pineapple canning industry began in 1889 when Kidwell's business associate, John Emmeluth, a Honolulu hardware merchant and plumber, produced commercial quantities of canned pineapple. Emmeluth refined his pineapple canning process between 1889 and 1891 and in $\approx 1891$ packed and shipped 50 dozen cans of pineapple to Boston, 80 dozen to New York, and 250 dozen to San Francisco. The test product was well received, but the profit margin was slim and he lost money because of the $35 \%$ duty on processed fruit imports to the United States (Larsen and Marks, 2010, p. 53). Kidwell and Emmeluth established the Hawaii Fruit and Packing Company in 1892 and built a small cannery. The business was closed and the cannery was sold to the Pearl City Fruit Company after the 1898 season because the crushing tariffs and high shipping costs made the venture unprofitable. In 1893 there were 13 pineapple growers, mostly on Oahu, with almost 400,000 plants in the ground and most fruits went to the fresh market. In 1897, almost 158,000 fruits were exported to the U.S. mainland. Production declined after 1897 and by 1901 no data on pineapple fresh fruit exports were collected (Larsen and Marks, 2010, p. 57).

Several events occurred in 1898 that facilitated the development of the new pineapple canning industry. First, the annexation of Hawaii in that year resulted in the revocation of the $35 \%$ duty on Hawaiian canned pineapple. Second, the Republic of Hawaii legislature passed a law that made some 526.3 ha (1300 acres) of government land near Wahiawa available for homesteading once a pasture lease expired. Lastly, Byron O. Clark, Territorial Commissioner of the Board of Agriculture and Forestry, helped bring 13 southern California families to Wahiawa to homestead the land made available under the new law. These early migrants and James Dole, who arrived in 1899, formed the nucleus of what would eventually become the largest pineapple industry in the world (Auchter, 1951; Larsen and Marks, 2010, p. 68-69). Dole quickly established relationships with prominent citizens in Hawaii, including Governor Sanford B. Dole, his second cousin. These relationships helped to assure that his venture into pineapple growing and canning was not starved for capital (Larsen and Marks, 2010, p. 80).

Although sugarcane was "king" in Hawaii, untilled government land was in pasture rather than sugarcane because it was too dry for unirrigated sugarcane and the elevation was too high for irrigated cane (Higgins, 1912). Sugarcane on Oahu was irrigated with groundwater 
and pumping costs made irrigation unprofitable above $\approx 183 \mathrm{~m}(600 \mathrm{ft}$ ) elevation (Wadsworth, 1933). Even when the Wahiawa dam at an elevation of $\approx 260 \mathrm{~m}$ was completed in 1907 , the water collected in the reservoir was almost all distributed to sugar plantations at lower elevations (Wadsworth, 1933).

It may have been fortuitous that the elevation of Wahiawa was $\approx 60 \mathrm{~m}$ too high for sugarcane because it is now common knowledge that the best pineapples in terms of sugar content and sugar-acid balance come from areas in Hawaii with an elevation of $\approx 300 \mathrm{~m}$. As the industry expanded on Oahu, most pineapple plantations were established at elevations above $180 \mathrm{~m}$. Lands at lower elevation were already planted to sugarcane because their shallower slopes made them easier to irrigate.

The recently arrived homesteaders cleared land, built homes, and at first planted food and fodder crops. Byron O. Clark had obtained a small pineapple farm planted with 'Smooth Cayenne' plants near Pearl City in 1898 before the prospective homesteaders had left California. Clark's farm provided the first pineapple plants grown on the homesteaded lands near Wahiawa and they grew so well that other homesteaders followed suit (Auchter, 1951). James Dole established the Hawaiian Pineapple Company (HPC) in 1901 and is "usually considered to have produced the first commercial pack of 1,893 cases of canned pineapple in 1903" (Auchter, 1951).

The pineapple plantation concept quickly spread to Kauai and Maui, perhaps because the already well-established sugar industry provided the near-ideal plantation model for those to whom it was not initially obvious. As the industry expanded, the cases of canned pineapple grew steadily while the number of canneries fluctuated (Fig. 1) (Auchter, 1951; Ten Bruggencate, 2004). By $\approx 1930$, after multiple reorganizations and consolidations, four companies came to dominate the Hawaii pineapple canning industry and all survived at least into the 1960s. These survivors were HPC; Libby McNeil \& Libby (LML), a major continental U.S. canner based in Chicago that became established in Hawaii in 1910; the California Fruit Canners Association, which acquired a Hawaiian pineapple canning company in 1911 [in 1916 it merged with three other U.S. West Coast canners to form California Packing Corporation (Calpak)]; and a group of companies affiliated with the sugar factor Alexander \& Baldwin that eventually became Maui Pineapple Co. (MPC) (Hawkins, 2011).

The first pineapple company on the island of Kauai was established in 1906. Over the years several additional companies were organized there, some by citizens of Japanese ancestry. Of the Kauai companies, only Hawaiian Fruit Packers (HFP), which was formed in 1937 by the reorganization of a company initially started by a group of ethnic Japanese growers, survived into the 1960s. Stokeley-Van Camp bought stock in the company in 1939 and became the exclusive distributor for its entire production (Auchter,

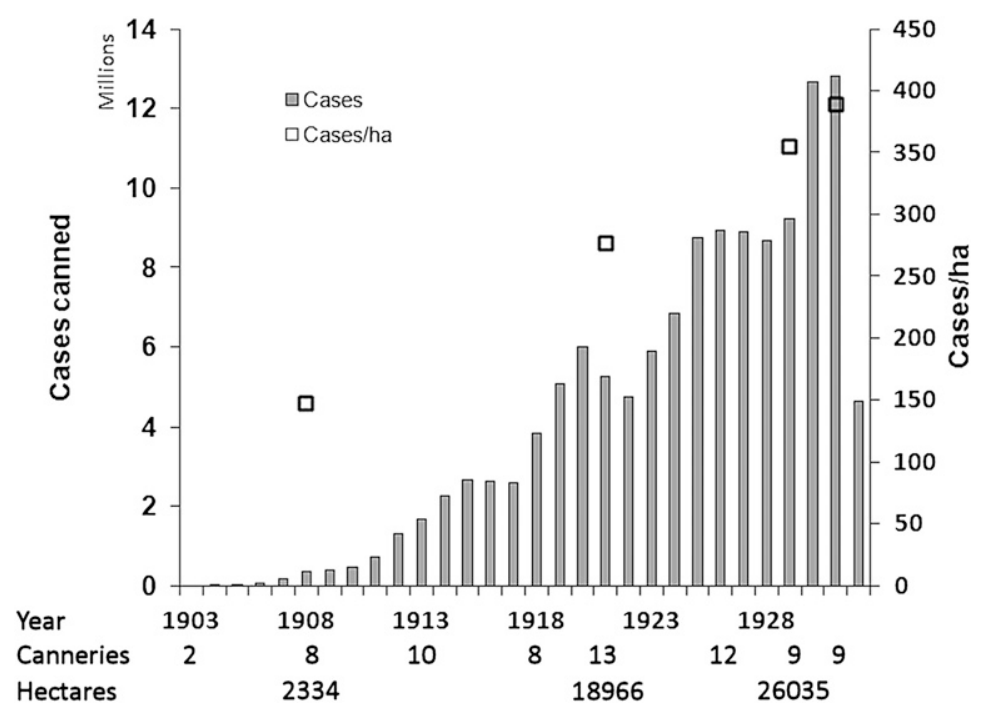

Fig. 1. Cases of pineapple canned, cases per hectare, operating canneries and selected data on area in crop in Hawaii from 1903 to 1932 (Auchter, 1951; Hawkins, 2011; Larsen and Marks, 2010).

1951). Ethnic Japanese also established pineapple farms on Oahu and Maui (Hawkins, 2011).

Japanese men were brought to Hawaii between 1885 and 1908 as indentured laborers for the sugar industry. Once their period of indenture was completed, many left to work in the pineapple industry because of easier working conditions, more freedom, and greater opportunity for advancement (Hawkins, 2011). In $1908, \approx 7.5 \%$ of the pineapple lands were controlled by growers of Japanese ancestry (Hawkins, 2011). A number of the farms operated by ethnic Japanese supplied pineapples to larger companies that grew as well as canned pineapple. In 1913, the greatest number of ethnic Japanese growers were on Oahu and 220 of those growers formed the Oahu Island Pineapple Growers Cooperative with over 2966 ha (7325 acres) under cultivation (Hawkins, 2011). In 1920, 87.7\% of the small pineapple farms were owned or operated by ethnic Japanese (Hawkins, 2011). As the pineapple industry consolidated, the number of the small farms run by ethnic Japanese gradually declined. However, Maui Pineapple Co. bought pineapples from a grower of Japanese ancestry for the cannery until it closed in 2007 and then purchased reduced volumes of fresh fruits through the end of 2009. The last large group of Asian immigrants came to Hawaii from the Philippines. By 1920 Filipinos comprised a significant segment of the plantation workforce and that remains the situation to this day.

Initially, pineapple yields, expressed as cases/ha, were very low. In 1908, pineapples occupied fewer than 2429 ha (6000 acres) (Hawkins, 2011); only $\approx 344,000 \quad 21.8-\mathrm{kg}$ (48 $\mathrm{lb}$ ) cases of canned product were produced (Larsen and Marks, 2010), and yields were less than 150 cases/ha (Fig. 1). Can size details were not available until the 1932-33 year. In that year and for many years afterward, there were nine can sizes. The various packs included slices, the most valuable of the canned products, as well as chunks, crushed or shredded, and juice (Auchter, 1951). Yields were low because planting densities were less than half the densities that became common by the 1930s (Larsen and Marks, 2010).

The new industry encountered a number of problems. The first that limited expansion of the planted area was a severe chlorosis that was observed in $\approx 1900$ (Auchter, 1951). The chlorosis occurred on large areas of so-called black soils that were high in manganese. The problem was not encountered in soils at higher elevations where rainfall was higher and soils were more highly leached and had lower $\mathrm{pH}$ values. The disorder was described and associated with manganese levels in soil (Kelley, 1909). Some years later Johnson (1916) discovered that high manganese rendered soil iron unavailable to pineapple plants and reported that sprays of iron sulphate would cure the problem. Johnson may have discovered the cure independently or he may have read of a similar lime-induced chlorosis problem of pineapple in Puerto Rico that was cured with iron sulphate sprays (Gile, 1911). Hoyt, an HPC employee, developed a mule-drawn sprayer to apply the iron sulphate solution and this ushered in the era of foliar fertilization of pineapple (Larsen and Marks, 2010, p. 150). With the chlorosis problem solved, the area planted to pineapple reached 18,966 ha by 1921 . Foliar sprays with iron sulphate and other innovations developed by the industry or the Hawaii Agricultural Experiment Station (HAES), which included increasing planting densities to 24,700 plants/ha or more, had improved yields such that cases per hectare reached 277 in 1921 (Fig. 1).

The "Banker's Panic" of 1907 caused pineapple sales to drop sharply and by early $1909,70 \%$ of the 1908 production of over 343,000 cases was still in cannery warehouses. The Hawaiian Pineapple Growers' Association (HPGA), which included HPC 
and six other pineapple companies, was formed in 1908 to deal with the problem (Auchter, 1951). A marketing study showed only limited sales in many large U.S. mainland cities, so salesmen were sent to such areas to market the glut of canned pineapple. Some success was achieved, but it was an advertising campaign, launched at a cost of $\$ 50,000$, that caused demand to surge (Larsen and Marks, 2010 , p. 140). The advertising campaign was supported by grower assessments based on the size of their canned pack. It was the first generic (not label or company-specific) advertising campaign in the U.S. food processing industry, preceding a similar campaign by the California orange industry by a few months (Hawkins, 2011).

The HPGA was disbanded in December of 1912 and was immediately replaced by the Hawaiian Pineapple Packers' Association (HPPA) with James Dole elected as president (Auchter, 1951). The bylaws of the organization covered the main issues confronting the new industry and included: 1) promote the common interests of the pineapple packers of the Territory of Hawaii; 2) undertake and encourage the scientific development of pineapple culture; 3) maintain a sufficient labor supply; 4) improve packing methods and equipment; 5) maintain and advance high standards for all products of the pineapple packing industry; 6) advertise and increase the demand for Hawaiian pineapple products; 7) seek the passage of laws beneficial to the pineapple industry; and 8) obtain the best possible transportation terms and facilities.

The HPPA began funding research at the experiment station of the Hawaiian Sugar Planters Association (HSPA) in 1914 to supplement the work of the HAES. The HSPA experiment station was established in 1895 , more than five years before the HAES existed, to carry out research on sugarcane. The joint research program included the breeding of pineapple to attempt to develop a Smooth Cayenne cultivar that was resistant to mealybug wilt (Lyon, 1915). In 1917 the Trustees of the HPPA leased 0.8 ha ( 2 acres) of land for the planting of seedlings produced by the program and additional land was leased in 1919 (Auchter, 1951). 'Smooth Cayenne' clones with partial resistance to mealybug wilt were found but breeding and selection for mealybug wilt resistance was not pursued because the resistance was insufficient (Rohrbach et al., 1988). By 1930, the wilt problem had become so serious that some growers considered establishing plantations outside of Hawaii (Rohrbach et al., 1988). Research showed that ants moved the mealybugs into the field so research focused on a way to keep ants out of the field. It was found in 1925 that ant fences bordering fields and sprayed with petroleum products would keep the ants out of the fields. Research by Calpak showed that pineapple border guard beds planted perpendicular to rows in the field would achieve the same result because ants preferred to move down rows rather than across them. The Calpak technique remained in use in some fields into the 1950s (Rohrbach et al., 1988); however, once effective insecticides became available, they replaced the physical controls (Rohrbach and Johnson, 2003).

The industry association name was changed in 1922 to Association of Hawaiian Pineapple Canners (AHPC) and cooperative marketing continued to be done periodically, but few other organizational changes were made. Despite the name change, the major objectives of AHPC remained research, a forum for the industry, industry publicity and oversight, worldwide data collection, and interaction with governmental agencies (Hawkins, 2011; Larsen and Marks, 2010, p. 142).

The cooperative research program with the HSPA was replaced in 1924 by a large research facility supported by self-imposed levies on pineapple production (Ten Bruggencate, 2004). Both the HSPA and pineapple research programs were relatively unique in American agriculture because they were funded primarily by grower assessments rather than by government. The new pineapple research program was housed in buildings adjacent to the University of Hawaii campus. In the 1926-27 University of Hawaii catalog, the AHPC research program supported 13 staff, two of whom had PhDs. The 1929-30 catalog listed five faculty in agriculture employed by the University of Hawaii, whereas the AHPCsupported program had grown to 28 total staff, 22 scientific staff, seven with doctorates, five with Master's, and the remainder with Bachelor's degrees.

Consistent with the social order of the time, the large plantations had a male-dominant all-white management hierarchy. Jung (2006) suggests that the business oligarchy in interwar Hawaii actively discouraged the middle class ambitions of Hawaii's non-white communities to maximize the number of potential plantation laborers. However, the AHPC research program apparently had a more liberal social outlook because Helene Morita, B.S., Assistant Nematologist, was among the staff in 1926-27. This probably reflected the fact that the University of Hawaii, as a public university, endeavored to uphold "democratic principles within the University" regarding race (Kamins and Potter, 1998). By 1929-30 the professional staff was remarkably diverse in terms of ethnicity as well as sex and included Morita; Assistant Physiologists Beatrice Krauss, B.S., and Eichi Masunaga, B.S.; Shizuo Harada, B.S., Assistant; Mary Kamm, B.S., Assistant Pathologist; and Carl A. Farden, B.S., Assistant Chemist; Farden was an ethnic Hawaiian. The senior scientific staff also supported the University of Hawaii's College of Agriculture by teaching classes and serving on graduate thesis committees.

An important innovation developed by Charles F. Eckart of the HSPA in 1914 was asphalt-impregnated paper mulch for weed control. John Whitmore of the HPC saw the value of the mulch, which increased pineapple plant growth rates, whereas yields were 22.4 to $33.7 \mathrm{t} \cdot \mathrm{ha}^{-1}$ ( 10 to 15 tons/acre) greater (Hawkins, 2011). HPC bought the rights to the mulch for $\$ 50,000$ and patented its use for pineapple and the application of the mulch was soon mechanized (Lyon, 1922). By 1932, HPC had collected royalties on the patent from other Hawaii pineapple growers totaling \$735,186 and James Dole considered this one of his more valuable contributions to the company (Larsen and Marks, 2010, p. 188). Paper mulch was eventually superseded by plastic and all pineapples grown by plantations in Hawaii were and are planted through mulch. In addition to helping to control weeds, the soil temperature was higher under the mulch. Planting was seasonal, mostly in the fall, so raising soil temperatures during the cooler months of the year resulted in large increases in plant growth (Auchter, 1951).

As the industry grew in size, innovations in the cannery were essential to increased cannery throughput and reduced labor costs. A major advance resulted when HPC hired Henry Ginaca in 1911 and charged him with developing a machine that produced fruit cylinders at a much higher rate. While developing the final model of the improved machine, Ginaca patented 11 innovations, all of which were assigned to HPC. By 1913 the improved machine could process up to 100 fruits per minute (Hawkins, 2011) and by 1918, HPC was selling Ginaca machines to processors for between $\$ 3500$ and $\$ 4200$ (Larsen and Marks, 2010, p. 92).

HPC became the largest pineapple producer in the world when the company purchased most of the island of Lanai in 1923. Fruit produced there was barged to Honolulu for processing. By 1931, pineapple production exceeded 12 million cases as a result of both expansion and improvements in productivity. Cases per hectare had increased from 277 in 1921 to 389 where it remained until 1949 (Figs. 1-2). The total area devoted to pineapple production peaked at 36,032 ha (89,000 acres) in 1936 (Hawkins, 2011) and when data were again available in 1947 , the area in pineapple had decreased by 8097 ha (Fig. 2). However, the decline in planted area was more than offset by increased yields. As a result of improvements made by the industry and its successful research program, productivity had increased to 500 cases/ha in 1949.

Early in the 20th century significant quantities of canned pineapple were being produced outside of Hawaii, mostly in British Malaya. In 1911 over 700,000 cases were packed in Singapore, a pack similar in size to that of the Hawaii industry of the time. However, most of the pack went to the United Kingdom. By 1940 Japanese canners in Taiwan packed over two million cases but only a small fraction entered the United States (Hawkins, 1989). In-shipments of canned pineapple from foreign sources to the United States were small during the first 30 years of the industry and averaged only 70,000 cases between 1924 and 1927, whereas more than eight million cases were shipped in annually from Hawaii (Hawkins, 2011). By 1940, $\approx 15 \%$ of the canned pineapple sold in the United States was produced outside of Hawaii (Hawkins, 2011). However, between 1930 and 


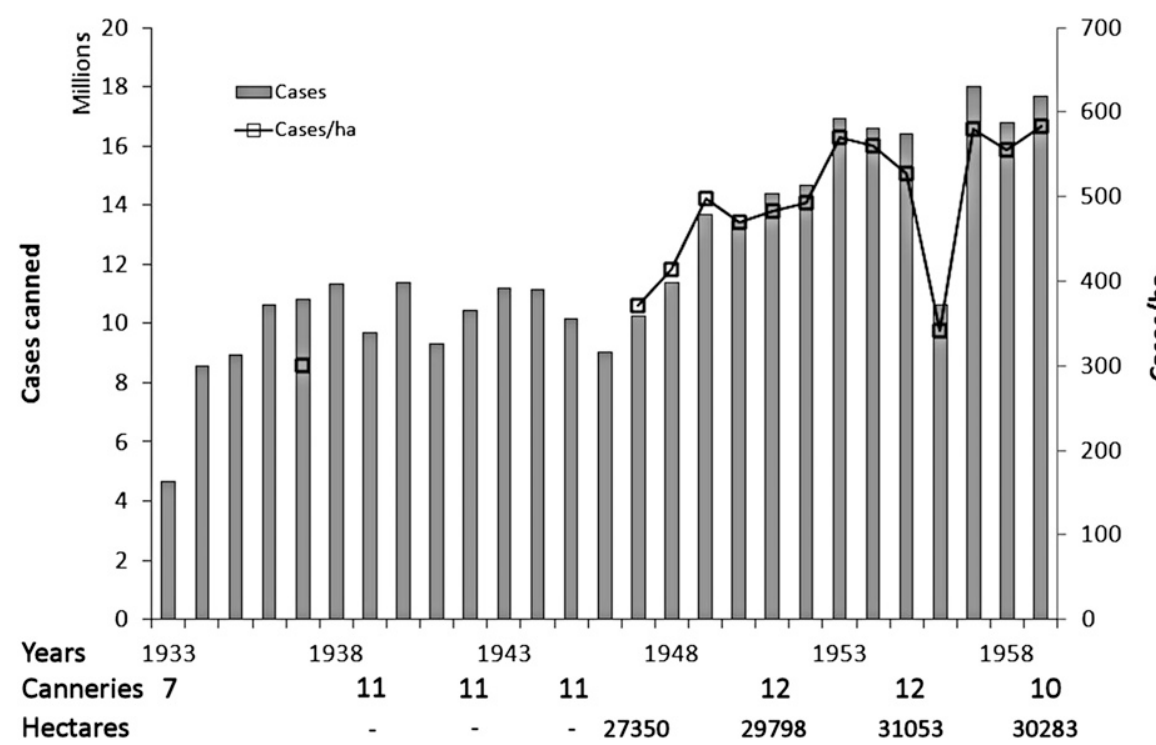

Fig. 2. Cases of pineapple canned and cases per hectare and selected data on canneries and, when available, land area planted to pineapple in Hawaii from 1933 to 1959 (Auchter, 1951; Larsen and Marks, 2010). Dashes indicate no data available.

1940, no foreign pineapple canner posed a serious threat to the dominant position held by Hawaii canners in the U.S. marketplace.

The world depression that began in 1929 did not seriously impact the Hawaii pineapple industry until 1931 (Hawkins, 1989). By 1932, mostly as a result of severe financial difficulties caused as a result of selling canned pineapple at a loss, cases produced plummeted (Fig. 1). HPC became financially overextended and, under pressure from its board to reorganize, James Dole, a pinnacle of the industry for over 30 years, was forced to resign as president of the company in 1932 . The AHPC was superseded in 1933 by the Pineapple Producers Cooperative Association (PPCA). The PPCA was replaced by the Pineapple Growers Association of Hawaii in 1944 and that organization survived until early in the 21 st century. The Pineapple Research Institute of Hawaii (PRI) was a department of the PPCA until 1944 when it was established as a separate industry-funded non-profit research institute (Auchter, 1951).

The PPCA incorporated the additional function of a production pool or cartel that controlled the output and marketing of canned pineapples (Hawkins, 1989); legal advice obtained in the late 1930s suggested the cartel was illegal. In addition to controlling supply, the PPCA embarked on an extensive marketing campaign that specifically targeted the upper segment of the American market for food products (Hawkins, 2009). In November of 1932, the PPC launched a \$1 million marketing campaign. That was followed by additional advertising campaigns in 1933 and 1934. By 1934, exports to the U.S. mainland had recovered to 12 million cases (Hawkins, 1989 ; note that there is not always correspondence between production and exports).

The recovery of the Hawaii pineapple industry was also aided when the HPC developed the technology to produce a high-quality pineapple juice. Juice production increased from 6,000 cases in 1933 to 700,000 in 1934 and had reached 7.5 million cases by 1936 (Hawkins, 1989). Juice production provided an outlet for the overproduction of fruit and significantly increased industry profitability (Hawkins, 1989). By 1941, juice exports reached a pre-war peak of 13.2 million cases, whereas industry receipts increased from $\$ 1000$ in 1933 to $\$ 21.3$ million in 1941.

During the period from $\approx 1925$ through 1940, innovations in the Hawaiian pineapple industry developed by individual companies or by their cooperative research organization led to a high degree of mechanization on the plantations and in the canneries. The major innovations included the laying of mulch paper by machines that also injected fumigant. Iron chlorosis was controlled by biweekly sprays of iron sulphate solution using boom sprayers, some with double booms that

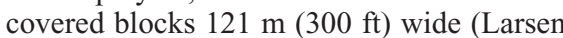
and Marks, 2010). Ammonium sulphate was used quite widely as a sidedressing by 1912 , but other improvements in fertilization practices also occurred on individual plantations. However, Auchter (1951) found no published records of how such improvements were adopted over the years. Zinc was found to be lacking in soils in some areas and was eliminated, either by soil application of zinc sulphate or by a foliar spray that included zinc. Plant calcium deficiency was also identified and rectified by liming, mainly to supply lime rather than to increase soil $\mathrm{pH}$. Adjustment of soil $\mathrm{pH}$ was not practiced because $\mathrm{pH}$ levels below 5.0 helped suppress Phytophthora sp. root and heart rot. Although iron was already being applied as a foliar spray, most other fertilizers were applied to the soil or into the plant leaf axils. In the early 1930s, researchers at the PPCA discovered that plants responded more quickly to sprays of dilute liquid nutrient solutions than to dry applications (Auchter, 1951) and that discovery eventually led to the foliar application of nitrogen with iron sulphate. The concept of crop logging for the measurement of plant growth and assessment of plant nutrient status was introduced in the 1940s (Nightingale, 1942a, 1942b) and was in widespread use by the 1950s (Sanford, 1962). By the 1950s, all the large plantations were applying foliar sprays that included iron sulphate and nitrogen, usually as urea, at biweekly intervals.

The technique of forced induction of flowering of pineapple using smoke was accidentally discovered in the latter part of the 19th century in the Azores Islands where pineapples were being grown in greenhouses (Collins, 1960). Rodriquez (1932) found that the active ingredient in smoke was ethylene and a technique was developed for its application to pineapple (Kerns and Collins, 1937). Later research showed that 1-naphthaleneacetic acid could also force pineapple (Clark and Kerns, 1942). However, forced induction of flowering, which peaked harvests and increased labor productivity, did not come into widespread use until after World War II (WWII). Now forced flowering is an essential cultural practice in the production of fresh pineapple because it allows fruit to be produced throughout the year.

Pesticide use also expanded after the war, resulting in improved control of mealybugs, nematodes, and weeds. Soil fumigation was used to control root knot and reniform nematodes, initially with chloropicrin (Johnson and Godfrey, 1932), later with a mixture of 1,3-dichloropropene-1,2-dichlorpropane (Carter, 1943), and still later with ethylene dibromide (EDB) and dibromochloropropane (DBCP). Fumigation preserved the motherplant root system, making the harvesting of a second or ratoon crop from the mother plant a viable option and a common practice. Up to three ratoons could be harvested before the plants were destroyed by disking, after which fields were prepared for replanting. Multiple passes with the disk were essential for the complete destruction of plants. Incomplete destruction, particularly of the desiccationresistant pineapple stems, resulted in pineapple becoming a serious weed pest in succeeding crops.

EDB and DBCP were particularly valuable for post-planting control of nematodes. With the adoption of fumigation to control nematodes, retention of a volatile fumigant was an additional important benefit of paper, and later plastic, mulch. Another benefit of mulch was improved water distribution (Ekern, 1964), which helped speed plant establishment. Insecticides were used to control mealybugs, the most important insect pest of pineapple in Hawaii, or the ants that protected them.

Pesticides were not without their problems. After a number of years of use, it was discovered that $\mathrm{EDB}$ and $\mathrm{DBCP}$ did not readily degrade in soil and gradually percolated to groundwater. That contamination resulted in the need to use activated carbon filters to clean up water supplied to the new 
town of Mililani, which was being developed by Castle and Cooke on lands formerly planted to pineapple. A large DBCP spill at Del Monte (Calpak was renamed Del Monte in 1967) required major remediation (EPA, 2011; Oki and Giambelluca, 1987). Another pesticide contamination problem that garnered national publicity was the discovery that milk from cows and nursing mothers was contaminated with above-tolerance levels of heptachlor, a persistent chlorinated hydrocarbon insecticide applied to pineapple for ant control (Larsen and Marks, 2010, p. 330; Smith, 1982). The heptachlor in the milk came from green-chopped pineapple fed to dairy cattle. Residue analysis of pineapple leaves showed there was no detectable heptachlor in that tissue. However, the company that produced the green-chopped pineapple saw an opportunity to increase yields by lowering the cutting head to also chop the stems. Later analysis showed that the source of the heptachlor in milk was from an accumulation of the insecticide in the leaf axils adjacent to the stem.

Planting was done by hand, as it still is for the most part, although Larsen and Marks (2010) enumerate multiple efforts to develop pineapple planting machines, some of almost unbelievable complexity. These machines were in use for a few years, but all had shortcomings that caused them to eventually end up in plantation "bone yards." Fruit was being harvested into lug boxes that were loaded onto trucks for transport to the cannery until near the end of WWII. In 1944, MPC developed a conveyor boom that transported fruits picked by workers to bins on a truck (Larsen and Marks, 2010). That and other innovations that took place in the industry increased worker productivity and likely helped keep the price of canned pineapple within the range of that for canned peaches, the main competitor of Hawaiian canned pineapple in U.S. markets (Hawkins, 2011). Up through $\approx 1960$, the Hawaiian pineapple industry set the world standards for pineapple culture, processing, quality control, and marketing. As the pineapple canning industry expanded outside of Hawaii after WWII, much of the technology developed in Hawaii was adopted by foreign producers of canned product.

Interest in overseas expansion of the pineapple industry began in 1913 when HPC explored possibilities in various parts of the world. These early explorations and a later trial in Fiji in 1929 were subsequently abandoned and the company did not establish a successful overseas plantation until the early 1960s. A trial begun by LML in Kenya in 1930 was also later abandoned (Hawkins, 2011). Calpak was the first Hawaii company to establish a foreign plantation, which Hawkins (2011) suggests was because of the lack of land for expansion in Hawaii. However, Ten Bruggencate (2004), a LML manager for many years, asserts that HPC, Calpak, and LML explored options overseas because of the devastating mealybug wilt. Once methods were developed to control the wilt, initial attempts to establish foreign ventures ceased. Only Calpak persisted in its efforts to establish an overseas plantation and began with exploratory plantings in Mindanao in 1925. A suitable site eventually was located in Bukidnon, Philippines, at an elevation of $\approx 600 \mathrm{~m}$. The climate was similar to, but wetter than, the area around Wahiawa, HI. The Hawaiian 'Smooth Cayenne' clones grew well there and the fruit quality was comparable to that of fruits produced in Hawaii. Calpak formed the PPC in 1928 and by 1930 a cannery had been built at Bugo on the coast to process the first harvest. By 1940, production had increased to 919,000 cases (Hawkins, 2011). The PPC cannery and the well-established canning industries in British Malaya and Taiwan were all shut down or destroyed by the war.

\section{DECLINE OF THE PINEAPPLE INDUSTRY IN HAWAII}

Atherton Richards, a HPC board member, saw the potential for loss of the U.S. market to foreign competition initiated by Hawaiibased companies, principally Calpak. Richards testified as an individual in support of legislation submitted to the 1941 Hawaii legislature that would ban the export of pineapple planting material that could be used to start plantations in the Philippines or South America (Larsen and Marks, 2010, p. 201). The bill passed the legislature but was killed by Governor Poindexter's pocket veto. Then WWII intervened and the status quo was maintained until after the war.

The production of Hawaiian canned pineapple was sustained throughout the war (Fig. 2) but finding sufficient labor to keep the industry going was difficult because $30 \%$ or more of the workers in the industry left for the military or for defense industry jobs (Auchter, 1951). After the war, the PPC was restarted. HPC made unsuccessful forays into Cuba in 1947 and Mexico in 1948 (Larsen and Marks, 2010, p. 208), but the land area in pineapple also grew at home (Fig. 2).

Foreshadowing of the decline of the industry began in the 1960 s, mainly as a result of competition from canned packs produced in the Philippines and Thailand. By 1950, PPC had recovered to the extent that more of the Pineapple Growers Association fruit allocation to Calpak came from the Philippines than from Hawaii. Production was also growing elsewhere with 3.82 million cases produced in 1950 in Taiwan, Malaya/Singapore, Okinawa, South Africa, Australia, Côte d'Ivoire, and "all other" areas; by 1969 , production in those countries totaled 24.1 million cases, whereas Hawaii's production had only increased from 11.95 to 12.85 million cases (Anonymous, 1972). The report (Anonymous, 1972) also noted that labor represented half of Hawaii's cost of production and that Hawaii's hourly labor costs ranged from $\$ 2.64$ to $\$ 3.69$, whereas the labor cost for growers in the Philippines and Taiwan ranged from $\$ 0.08$ to $\$ 0.24$ per hour.
Shipping and labor strikes in 1971 highlighted the competitive problems confronting the Hawaii pineapple industry and Malcolm McNaughton, president of Castle and Cooke, spoke pessimistically about the future of corporate agriculture in Hawaii (Larsen and Marks, 2010, p. 500).

Several of the smaller Kauai and Maui pineapple companies closed in the late 1960s and in 1969, HFP on Kauai, the last cannery remaining there, announced plans to cease planting in 1969 . The cannery was closed in Oct. 1973. In Apr. 1973, the U.S. Tariff Commission received a petition from Local 142 of the International Longshore and Warehouse Union requesting assistance on behalf of the workers on the presumption that StokelyVan Camp Inc., the sole marketer of HFP pineapple, was importing pineapple into the United States in quantities that caused unemployment or underemployment of union workers. The Commission succinctly summed up the competitive issues confronting the Hawaii pineapple industry in their findings. These included shipping costs from Hawaii to the mainland that exceeded the costs from the Philippines and Thailand as a result of the Jones Act, the termination of regular ocean shipping service to Gulf and East Coast ports in 1968, and price competition from domestic fruits and juices. However, the Commission found that the primary factor contributing to the higher cost of Hawaiian canned pineapple was unit labor costs, which accounted for half of production costs and were $90 \%$ greater in 1972 than they had been in 1960 (Larsen and Marks, 2010, p. 429 430). Larsen and Marks (2010, p. 430) also noted that land costs were high in Hawaii and observed that a $0.5 \%$ gross income tax on products and the cost of pineapple research also contributed to the higher costs in the Hawaii industry.

Although some were pessimistic about the future of pineapple in Hawaii, MPC set new profit records between 1976 and 1984 (Larsen and Marks, 2010, p. 204). During those years, only the fresh fruit segment of the industry experienced growth (Fig. 3). As the Hawaii industry declined, expansion overseas by Hawaii companies continued as Castle and Cooke established a plantation and cannery, DoleFil, in 1964 in the Cotabato area of Mindanao. By the mid-1980s DoleFil was producing $202,429 \mathrm{t}$ of pineapple with 26,315 t marketed fresh in Japan (Larsen and Marks, 2010, p. 636). However, the Hawaii pineapple industry was not the only one to decline. Industrialization in Taiwan eliminated that country as a significant competitor by 1980 (Table 1), but the development of the 33,000-ha PT Great Giant Pineapple Co. (PTGG) plantation in Sumatra in 1979 introduced another large and low-cost competitor. MPC (renamed Maui Land and Pineapple Co. in 1969 as more resources were committed to resort development) formed a strategic alliance with, and provided advice to, PTGG as it developed. In return, PTGG provided MPC with low-cost canned pineapple, thus providing MPC access to the non-premium 


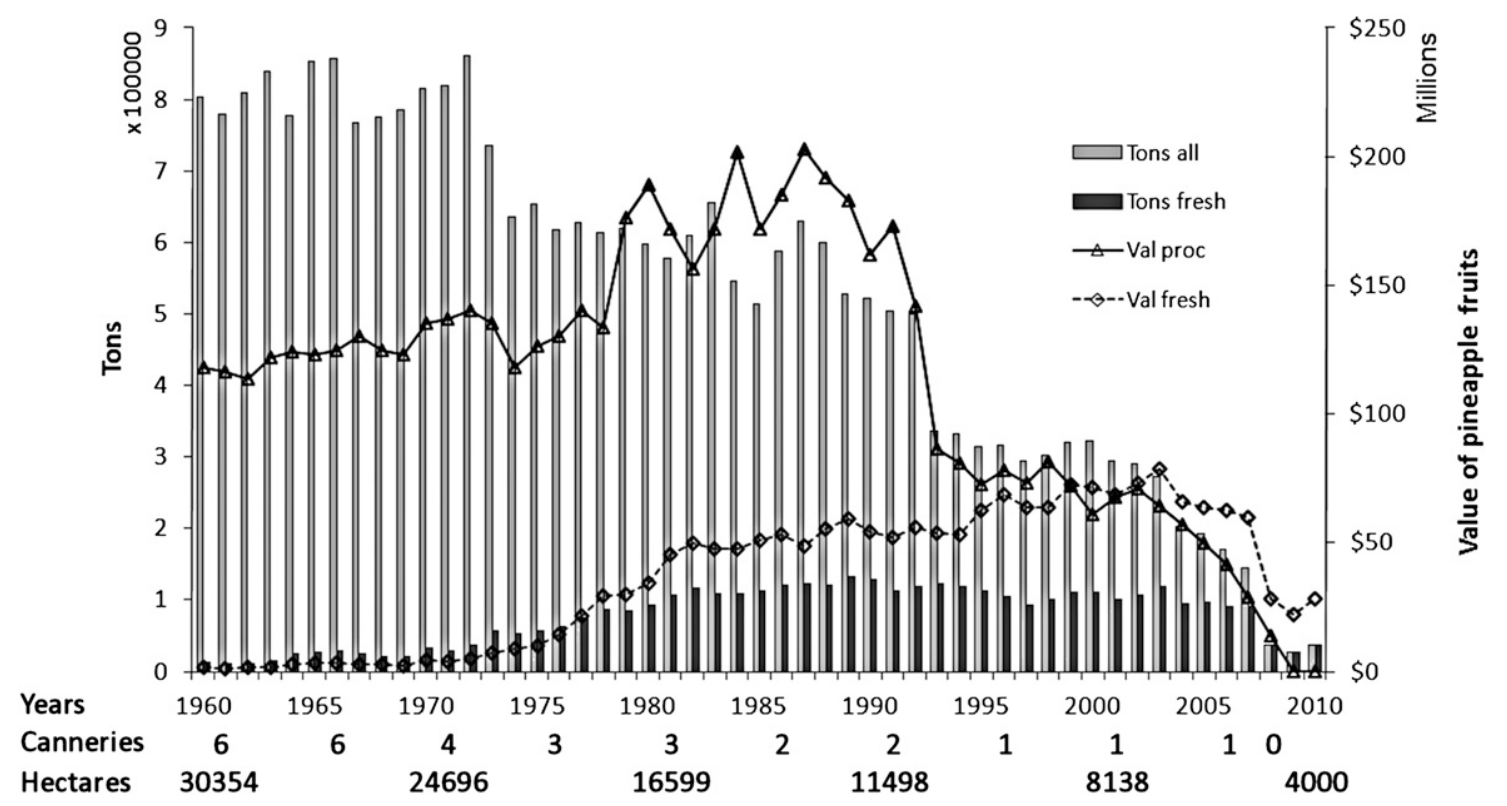

Fig. 3. Total tons pineapple produced in Hawaii (Tons-all), tons sold fresh (Tons fresh), farm gate value of pineapple sold, value of tons sold fresh, and selected data on canneries and land in pineapple. (Anonymous, 1961-1997; Hidano and Nakasone, 2007; Martin and Osaki, 1998-2006; values from 2008 to 2010 are the authors' best estimates.)

Table 1. Percentage of world production of canned (C) and canned plus fresh (CF) pineapples exported from countries that produced 10 or more percent of either category for the period shown (data from Ten Bruggencate, 2004).

\begin{tabular}{|c|c|c|c|c|c|c|c|c|c|c|c|c|c|c|}
\hline \multirow[b]{2}{*}{ Location } & \multicolumn{2}{|c|}{1942} & \multicolumn{2}{|c|}{1950} & \multicolumn{2}{|c|}{1960} & \multicolumn{2}{|c|}{1970} & \multicolumn{2}{|c|}{1980} & \multicolumn{2}{|c|}{1990} & \multicolumn{2}{|c|}{2000} \\
\hline & $\mathrm{C}$ & $\overline{\mathrm{CF}}$ & $\overline{\mathrm{C}}$ & $\overline{\mathrm{CF}}$ & $\mathrm{C}$ & $\overline{\mathrm{CF}}$ & $\bar{C}$ & $\overline{\mathrm{CF}}$ & $\overline{\mathrm{C}}$ & $\overline{\mathrm{CF}}$ & $\overline{\mathrm{C}}$ & $\overline{\mathrm{CF}}$ & $\overline{\mathrm{C}}$ & $\mathrm{CF}$ \\
\hline Hawaii & 83 & 83 & 74 & 51 & 55 & 36 & 37 & 16 & 16 & 6 & 1 & 5 & 0 & 2 \\
\hline Philippines & War & War & 4 & 4 & 7 & 5 & 10 & 4 & 22 & 9 & 19 & 10 & 25 & 11 \\
\hline Thailand & 0 & 0 & 0 & 0 & 6 & 9 & 10 & 4 & 32 & 34 & 43 & 17 & 44 & 17 \\
\hline Taiwan & 8 & 8 & 5 & 3 & 9 & 6 & 10 & 5 & 4 & - & - & - & - & - \\
\hline Indonesia & 0 & 0 & 0 & 0 & 0 & 0 & 4 & 1 & 5 & 2 & 5 & 3 & 13 & 3 \\
\hline
\end{tabular}

canned pineapple market (Larsen and Marks, 2010, p. 516).

Hawaii companies continued to expand overseas with DM purchasing Kenya Canners Ltd. in 1968. In 1972, Castle and Cooke purchased a small canning company near Hua Hin, Thailand. A few years after the purchase, the Dole plantation had reduced pineapple production in Hawaii from 522, 727 to 318,181 t by reducing production at Wahiawa and Lanai. By 1991, only two canneries remained and the area in pineapple had also decreased (Fig. 3). When Castle and Cooke closed the Lanai plantation in 1992, the land in pineapple dropped further. By 1992 DoleThai was operating the third largest pineapple cannery in the world with PPC ranked first and DoleFil second (Larsen and Marks, 2010, p. 647).

As the cannery business was becoming less profitable, there was a gradual shift to fresh fruit production (Fig. 3), which about coincided with greatly expanded consumption of fresh fruits and vegetables in the developed world. Unlike most fruits grown in Hawaii, no quarantine restrictions were placed on fresh pineapple fruits imported into the U.S. mainland because cultivars with $50 \%$ or more 'Smooth Cayenne' parentage were not fruit fly hosts (Armstrong et al., 1979). However, as long as pineapples were still being canned, fresh out of Hawaii. It had long been recognized that 'Smooth Cayenne' was not the ideal fresh fruit because quality was poor in the winter as a result of high fruit acidity (Gortner et al., 1963). The few alternative cultivars, but primarily 'Queen', had small fruits, low yields, spiny leaves, and were prone to internal browning when refrigerated. However, as long as the canneries remained in operation, the plantation grew fruit for the cannery and the fresh market was a small side business. As the canneries closed, Dole and DM shifted to the production of fresh fruit. From 1960 until 2007, there was a gradual decline in tons of fruit produced and, coincidentally, a gradual increase in the proportion of tons of fruit sold fresh (Fig. 3). After MPC closed its cannery in 2007, all fruit produced was sold fresh. The early increases in fresh pineapple shipments from Hawaii were based entirely on 'Smooth Cayenne' clones, but that all changed after 1996.

\section{GLOBAL RISE OF FRESH 'MD-2' PINEAPPLE PRODUCTION}

The lack of good-quality fresh fruit cultivars that were also capable of producing high only 'Smooth Cayenne' fruits were shipped yields was at least in part the result of an industry focus on 'Smooth Cayenne' fruit. The poor quality of 'Smooth Cayenne' fruit produced in the winter was not a problem for the cannery because most of the fruit destined for processing was harvested during the summer when fruit quality was best and seasonal labor was more readily available. The industry focus on canning directed the PRI pineapple breeding program (Williams and Fleisch, 1993), which even in 1964 had as its primary objective the development of cultivars suitable for canning that would outyield 'Smooth Cayenne' (Johannessen and Kerns, 1964). Breeding of new pineapple cultivars is difficult because parents are highly heterozygous, self-incompatibility prevents the development of inbreds, and selection involves a multiplicity of characteristics (Williams and Fleisch, 1993). As a result of the poor success of the PRI pineapple breeding program, no crosses were made after 1972, the PRI physical plant was closed in 1975 , and the remaining seedlings were shipped to Maui for further evaluation (Williams and Fleisch, 1993).

Castle and Cooke left the PRI in 1971 and received a $60 \%$ share of those seedlings. The remaining seedlings were jointly owned by MPC and DM, and the best selections were distributed to the two companies in $\approx 1980$. In the late 1970s, DM established a plantation in Costa Rica to provide a source of fresh fruit for the eastern United States and Europe. The company's 'Smooth Cayenne' clone, Champaka 153, did not perform satisfactorily in the Costa Rican environment. In the mid-1980s DM shipped plants of PRI hybrid 73-114, named 'MD-2' after manager Frank Dillard's wife Millie, from Hawaii to Costa Rica (Bartholomew, 2009). The hybrid grew well in the Costa Rican environment and test marketing showed it to be preferred by consumers. 
'MD-2' pineapples, trademarked Del Monte Gold, were officially introduced to U.S. and European markets in 1996. Del Monte was purchased by R.J. Reynolds in 1979 and the fresh fruit business was sold in 1989 by what was then RJR Nabisco and renamed Fresh Del Monte Produce (FDMP). By 2002, FDMP's pineapple sales, presumably all 'MD-2', had grown to over $\$ 400$ million and boxes of the fruit sold for a premium in the European and U.S. markets (Frank, 2003). By early 2000, 'MD-2' fruit had almost completely replaced 'Smooth Cayenne' in the rapidly growing markets for fresh pineapples in the United States and Europe and devastated the 'Smooth Cayenne'-based fresh pineapple industries of Ghana and Côte d'Ivoire (Bartholomew, 2009).

In 2010, the 'MD-2' pineapple was named the American Society for Horticultural Science's 2010 Outstanding Fruit Cultivar (Anonymous, 2010). 'MD-2' was one of only two commercially successful pineapple cultivars produced by the world's largest pineapple breeding program. The other cultivar, PRI hybrid 73-50, named 'MD-1' by DM, was later patented by DM as 'CO-2' (Bartholomew et al., 2010). Both 'MD-2' and 'CO-2' have slightly higher ${ }^{\circ}$ Brix than 'Smooth Cayenne', but their superiority as fresh fruits was the result of significantly lower acidity, especially during winter, and greatly improved storability. 'Smooth Cayenne' fruits develop quite severe internal browning, a chilling injury, when refrigerated, a defect that is not present in 'MD-2', and ' $\mathrm{CO}-2$ ' is much less susceptible to the disorder than is 'Smooth Cayenne'. 'CO-2' achieved some success at MPC as Maui Gold ${ }^{\circledR}$ and is also grown by Dole (Castle Cooke was renamed Dole Food Company, Inc. in 1991) on Oahu and in the Philippines. The hybrid also is one of the main fresh fruit cultivars in Australia (G. Sanewski, personal communication).

With the success of 'MD-2' assured, FDMP began to rapidly convert their Hawaii plantation to 'MD-2' by importing planting material from Costa Rica to Hawaii in 2001. The Hawaii division shipped fresh and fresh-cut fruit to the U.S. West Coast until FDMP abruptly closed the plantation in 2007 . The Dole division in Hawaii introduced a lowacid pineapple in early 2000 but the quality was poor and it was replaced as quickly as possible with a Dole selection of 'MD-2' named MG3. 'MD-2' planting material became widely available after the "pineapple war" over rights to the cultivar were resolved (Frank, 2003; Greig, 2004; Janick, 2003). As a result of the market shift from 'Smooth Cayenne' to 'MD-2', independent growers in Ghana and the Ivory Coast quite rapidly abandoned 'Smooth Cayenne' and rapidly expanded the area planted to 'MD-2' as did independent growers in Costa Rica, Ecuador, and the Philippines. As a result of this rapid expansion in the supply of 'MD-2' fruits, fresh pineapple has become cheaper, resulting in "heterogeneous quality" (Loeillet et al., 2011).

The pineapple business of MPC closed in 2009 and a new company, Maui Gold
Pineapple Co., began growing Maui Gold ${ }^{\circledR}$ ('CO-2') in 2010 on $\approx 400$ ha of land leased from Maui Land and Pineapple Co. The newly formed corporation hopes its flatter organizational structure will help assure its success. Dole continues to grow fresh fruit on Oahu, primarily for the Oahu and tourist markets with $\approx 15 \%$ of their pack going to West Coast markets when shortages in the company's Central American supply occur.

The industry that dominated the U.S canned pineapple market for 60 years now exists primarily to supply local markets with fresh pineapples and to keep lands owned by Maui Land and Pineapple Company and Dole Food Company in agriculture to take advantage of the favorable tax base such lands enjoy. The industry grew and survived as a result of innovations in culture, mechanization of production in the field and cannery, a focus on product quality, and market-leading advertising campaigns. The circumstances that brought about the fall of the Hawaii industry are no different from those that have caused the demise of many industries in developed countries. The globalization of the international economy allowed companies in developed countries to relocate production to developing countries to take advantage of lower labor costs together with cheaper resources such as land and water. The systematic reduction of tariffs by developed countries since WWII accentuated this trend.

\section{Literature Cited}

Anonymous. 1886. Death of C.E. Henson. Honolulu Daily Herald. 28 Dec.

Anonymous. 1961-1997. Statistics of Hawaiian agriculture. Univ. Haw., College Agr., Agr. Ext. Serv., 1946-2005.

Anonymous. 1972. The impact of foreign pineapple production on the Hawaiian pineapple industry; Problems and recommendations. Hawaii Dept. Agr., Honolulu, HI.

Anonymous. 2010. 'MD-2' Pineapple named the American Society for Horticulture Science 2010 Outstanding Fruit Cultivar. Pine. News No. 17:2. 15 Dec. 2011. <http://ishs-horticulture.org/ workinggroups/pineapple/PineNews17.pdf>

Armstrong, J.W., J.D. Vriesenga, and C.Y.L. Lee. 1979. Resistance of pineapple varieties D-10 and D-20 to field populations of oriental fruit flies and melon flies. J. Econ. Entomol. 72:6-7.

Auchter, E.C. 1946. The pineapple industry: A brief review of its history, research, achievements and war jobs. Presented before the Congressional hearing in statehood for Hawaii. Pineapple Res. Inst. Haw., Honolulu, HI.

Auchter, E.C. 1951. People, research, and social significance of the pineapple industry of Hawaii. Pineapple Res. Inst. Haw., Honolulu, HI.

Bartholomew, D.P. 2009. 'MD-2' pineapple transforms the world's pineapple fresh fruit export industry. Pine. News No. 16:2-5. 15 Dec. 2011. http://ishs-horticulture.org/workinggroups/ pineapple/PineNews16.pdf>.

Bartholomew, D.P., G. Coppens d'Eeckenbrugge, and C.C. Chen. 2010. Fruit and nut register list No. 45. HortScience 45:716-756.

Carter, W. 1943. A promising new soil amendment and disinfectant. Science 97:383-384.

Clark, H.E. and K.R. Kerns. 1942. Control of flowering with phytohormones. Science 95: 536-537.
Collins, J.L. 1960. The pineapple: Botany, cultivation and utilization. Interscience Publishers Inc., New York, NY.

Coppens d'Eeckenbrugge, G., G.M. Sanewski, M.K. Smith, M.-F. Duval, and F. Leal. 2011 Pineapple. In: Kole, C. (ed.). Wild crop relatives: Genomic and breeding resources, tropical and subtropical fruits. Springer-Verlag, Berlin, Germany.

Dole, J.D. 1929. Some recollections of twenty-five years of the pineapple industry. Mid-Pacific Mag. 23:403-410.

Dole, R. and E.D. Porteus. 1990. The story of James Dole. Island Heritage Publishing, Aiea, HI.

Ekern, P.C. 1964. The evaportranspiration of pineapple in Hawaii. Res. Rpt. 109. Pineapple Res. Inst. Haw., Honolulu, HI.

EPA. 2011. Region 9: Superfund. Del Monte Corp. (Oahu Plantation). 30 Oct. 2011. <http://yosemite epa.gov/r9/sfund/r9sfdocw.nsf/3dec8ba32523 68428825742600743733/6305fd0b9e5e8088 $88257007005 \mathrm{e} 9468$ ! OpenDocument>.

Frank, R. 2003. Going for 'The Gold' turns pineapple world upside down. Wall St. J. 7(Oct).

Gile, P.L. 1911. Relation of calcareous soils to pineapple chlorosis. Univ. P.R. Agr. Expt. Sta. Bul. 11.

Gortner, W.A., C.H. Spiegelberg, G.G. Dull, and B.H. Krauss. 1963. Field-fresh pineapple for export. Res. Rpt. 99. Pineapple Res. Inst. Haw., Honolulu, HI.

Greig, I. 2004. Pineapple wars redux. Chron. Horticult. 44:5.

Hawkins, R.A. 1989. The pineapple canning industry during the World Depression of the 1930s. Bus. Hist. 31:48-66.

Hawkins, R.A. 1995. The Baltimore canning industry and the Bahamian pineapple trade, c.1885-1926. Md. Hist. 26:1-22.

Hawkins, R.A. 1997. An English entrepreneur in the Hawaiian Islands: The life and times of John Kidwell, 1849-1922. Hawaii. J. Hist. 31:149170.

Hawkins, R.A. 2009. Advertising and the Hawaiian pineapple canning industry, 1929-39. J. Macromark. 29:172-192.

Hawkins, R.A. 2011. A Pacific industry: The history of pineapple canning in Hawaii. I.B. Tauris, London, New York.

Hidano, R.W. and S.K. Nakasone. 2007. Hawaii pineapples annual summary. Haw. Agr. Stat. Serv., Haw. Dept. Agr., USDA, Honolulu, HI.

Higgins, J.E. 1912. The pineapple in Hawaii. Haw. Agr. Expt. Sta. Press Bul., Honolulu, HI.

Janick, J. 2003. Pineapple wars. Chron. Horticult. 43:17.

Johannessen, G.A. and K.R. Kerns. 1964. The variety development program as of mid-1964. Res. Rpt. 111. Pineapple Res. Inst. of Hawaii, Honolulu, HI

Johnson, M.O. 1916. The spraying of yellow pineapple plants on manganese soils with iron sulphate solutions. Haw. Agr. Expt. Sta. Press Bul. 51.

Johnson, M.O. and G.H. Godfrey. 1932. Chloropicrin for nematode control. Ind. Eng. Chem. 24:311-318.

Jung, M.-K. 2006. Reworking race: The making of Hawaii's interracial labor movement. Columbia Univ. Press, New York, NY.

Kamins, R.M. and R.E. Potter. 1998. Mālamalama: A history of the University of Hawai'i. Univ. Haw. Press, Honolulu, HI.

Kehlor, R.R. 1992. The history of Del Monte Pineapple in Hawaii. Del Monte Corporation, Honolulu, HI.

Kelley, W.P. 1909. The influence of manganese on the growth of pineapples. Haw. Agr. Expt. Sta. Press Bul. 23. 
Kerns, K.R. and J.L. Collins. 1937. The uses of acetylene to stimulate flower formation: A technique in pineapple breeding. Proc. Haw. Acad. Sci., 11th Ann. Mtg. 1935-1936. p. 25.

Larsen, J.L. and T.A. Marks. 2010. Hawaiian pineapple entrepreneurs 1894-2010. Creative Co., McMinnville, OR.

Loeillet, D., C. Dawson, and T. Paqui. 2011. Fresh pineapple market: From the banal to the vulgar. Acta Hort. 902:587-594.

Lyon, H.L. 1915. A survey of the pineapple problems. Haw. Plant. Rec. 13:125-139.

Lyon, H.L. 1922. A paper laying machine. Haw. Plant. Rec. 26:326-327.

Martin, D.A. and A. Osaki. 1998-2006. Hawaii pineapples annual summary. Haw. Agr. Stat. Serv. Hawaii Dept. Agr., U.S. Dept. Agr., Honolulu, HI.
Nightingale, G.T. 1942a. Nitrate and carbohydrate reserves in relation to nitrogen nutrition of pineapple. Bot. Gaz. 103:409-456.

Nightingale, G.T. 1942b. Potassium and phosphorus nutrition of pineapple in relation to nitrate and carbohydrate reserves. Bot. Gaz. 104:191223.

Oki, D.S. and T.W. Giambelluca. 1987. DBCP, EDB, and TCP contamination of ground water in Hawaii. Ground Water 25:693-702.

Rodriquez, A.G. 1932. Influence of smoke and ethylene on the fruiting of pineapple (Ananas sativus). Schult. J. Dept. Agr. Puerto Rico 16: 5-18.

Rohrbach, K.G., J.W. Beardsley, T.L. German, N.J. Reimer, and W.G. Sanford. 1988. Mealybug wilt, mealybugs, and ants of pineapple. Plant Dis. 72:558-565.
Rohrbach, K.G. and M. Johnson. 2003. Pests, diseases and weeds, p. 203-251. In: Bartholomew, D.P., R. Paull, and K.G. Rohrbach (eds.). The pineapple: Botany, production and uses. CABI Publ., Wallingford, UK.

Sanford, W.G. 1962. Pineapple crop log-concept and development. Better Crops Plant Food 46:32-43.

Smith, R.J. 1982. Hawaiian milk contamination creates alarm. Science 217:137-140.

Ten Bruggencate, J.K. 2004. Hawaii's pineapple century. Mutual Publ., LLC, Honolulu, HI.

Wadsworth, H.A. 1933. A historical summary of irrigation in Hawaii. Haw. Plant. Rec. 27:123162.

Williams, D.D.F. and H. Fleisch. 1993. Historical review of pineapple breeding in Hawaii. Acta Hort. 334:67-76. 